\title{
27. METALLOGENESIS IN THE PARECE VELA MARGINAL BASIN COMPLEX OF THE PHILIPPINE SEA, DEEP SEA DRILLING PROJECT LEG 59
}

\author{
Martha R. Scott, Department of Oceanography, and George W. Bolger, Department of Geology, \\ Texas A\&M University, College Station, Texas
}

\begin{abstract}
This chapter addresses the question of whether backarc spreading centers leave the same fingerprint of metal-enriched sediments that mid-ocean ridge spreading centers are so well known to leave. DSDP Legs 59 and 60 made an east-west traverse across the South Philippine Sea. Samples were collected in the Parece Vela Basin (Sites 449 and 450), the West Mariana Ridge (Site 451), and the Mariana Trough (Sites 452-460). No samples from the West Philippine Basin were analyzed, because original basal sediments had been eroded and replaced with coarse volcaniclastic breccia derived from the igneous basement itself (see Site 447 report, this volume). We analyzed basal-sediment samples from Holes 449 and 450 in the Parece Vela Basin (Leg 59) and from Holes 453, 459B, and 460A (Leg 60) for aluminum, calcium, magnesium, total iron, manganese, copper, colbalt, and nickel. Data and discussion of the results of Leg 59 are included in this report; those for Leg 60 are forthcoming in that volume.
\end{abstract}

The samples consisted of 1 to $5 \mathrm{~cm}$ plugs that were homogenized in an agate mortar and pestle. Aliquots of from 0.3 to $0.5 \mathrm{~g}$ were weighed to the nearest $10 \mu \mathrm{g}$ in Teflon beakers and dissolved in concentrated reagent grade $\mathrm{HCl}, \mathrm{HNO}_{3}$, and $\mathrm{HF}$. The samples were allowed to dry, redissolved in concentrated hydrochloric acid, and diluted to $100 \mathrm{ml}$ final volume $(1 \% \mathrm{HC} 1$ matrix $)$. Additional samples of USGS standards of basalt (JB-1) and marine mud (MAG-1) were digested concurrently for accuracy determinations.

The analyses were performed utilizing both flame (air-acetylene for $\mathrm{Mg}, \mathrm{Fe}, \mathrm{Mn}$, and $\mathrm{Cu}$; nitrous oxideacetylene for $\mathrm{Al}$ and $\mathrm{Ca}$ ) and flameless (HGA-2100 for $\mathrm{Co}$ and $\mathrm{Ni}$ ) atomic-absorption spectrophotometry. Concentrations were determined by comparison with appropriate dilutions of Fisher atomic-absorption standards, with a precision of better than $\pm 5 \%$ for all elements. Comparison of experimental results with published values for JB-1 (Flanagan, 1973) and MAG-1 (Manheim et al., 1976) showed that recoveries were within $\pm 6 \%$ for $\mathrm{Al}, \mathrm{Mn}, \mathrm{Ca}, \mathrm{Mg}, \mathrm{Fe}$, and $\mathrm{Cu}$ and $\pm 10 \%$ for $\mathrm{Co}$ and $\mathrm{Ni}$. The analytic results are listed in Table 1 .

Parece Vela Basin Sites 449 and 450 are respectively located west and east of the trough, which is identified as the now inactive spreading center that formed the basin (Kroenke and Scott, 1978). The sediment at Site 449 consists of 111 meters of upper-Oligocene to Pleistocene normal oceanic clays and nannofossil oozes. It should be noted that the last core [Core 13] above basement had a cored length of 6.5 meters, yet 9.0 meters of core were recovered. Probably the upper part of the core consists of material displaced from higher in the section; in all likelihood, the basal part of the core above igneous basement is in place.) The basalt basement at Hole 449 is reported by Kroenke and Scott (1978) to be "most likely of late Oligocene age." Karig (1975) has also suggested that the western side of the basin appears to be older than the Miocene. The sediment contact with basement was not preserved well enough in the coring process to study; the underlying basalt was reported to show moderate low-temperature alteration (Site 449 report, this volume).

Site 450 was drilled in the eastern Parece Vela Basin on the western flank of the West Mariana Ridge. The core penetrated a thick sediment wedge, 90 meters of Pleistocene to middle-Miocene pelagic clay, which grades downward to basaltic tuffs that continue to a depth of 330 meters (these tuffs were derived from volcanism on the West Mariana Ridge [Kroenke and Scott, 1978]). The sediment terminates in basalt, but it is not representative of basal sediment, because a baked metamorphic contact suggests an intrusive basalt. True basement is probably several hundred meters lower. The age of sediments above the intrusion are several million years younger than basement age based on either magnetic-age estimates (Langseth and Mrozowski, this volume) or geologic evidence (see Site 450 report, this volume).

The metal to aluminum ratios for samples from Hole 449 are plotted against depth in Figure 1. The vertical dashed lines represent average Pacific pelagic-clay (APC) ratios (Table 2). The sediments are generally enriched in $\mathrm{Fe}, \mathrm{Cu}, \mathrm{Co}$, and $\mathrm{Ni}$ with respect to average pelagic clays. The distribution of ratios shown in Figure 1 indicates that the greatest enrichment is found in the basal sediments-in the lower 2.5 meters of the core. This fits the pattern of metal enrichment delineated by Boström's data $(1970,1975)$ and suggests a strong parallelism between mid-ocean ridge spreading and back-arc spreading. That is, sediment forming at spreading centers of either type is enriched in metals by sea water that has circulated through the oceanic crust; as the spreading moves this newly formed basal sediment away from the center, the metal-enriched sediment is buried under normal, nonmetalliferous sediment. Kroenke and Scott (1978) have suggested that the IPOD Trough in the enter of the Parece Vela Basin may have been a small segment of the spreading center here.

Boström and Peterson (1969) have determined that a value of less than 0.4 for the $\mathrm{Al} /(\mathrm{Al}+\mathrm{Fe}+\mathrm{Mn})$ ratio is 
Table 1. Composition of basal sediments collected during DSDP Leg 59 at Holes 449 and 450.

\begin{tabular}{|c|c|c|c|c|c|c|c|c|c|}
\hline $\begin{array}{l}\text { Sample } \\
\text { (intervals in cm) }\end{array}$ & $\begin{array}{l}\text { Depth below Sea Floor } \\
\text { (m) }\end{array}$ & $\begin{array}{l}\mathrm{Fe} \\
(\%)\end{array}$ & $\begin{array}{l}\mathrm{Mn} \\
(\%)\end{array}$ & $\begin{array}{l}\mathrm{Ca} \\
(\%)\end{array}$ & $\begin{array}{l}\mathrm{Mg} \\
(\%)\end{array}$ & $\begin{array}{c}\mathrm{Al} \\
(\%)\end{array}$ & $\begin{array}{c}\mathrm{Cu} \\
(\mathrm{ppm})\end{array}$ & $\begin{array}{c}\text { Co } \\
\text { (ppm) }\end{array}$ & $\begin{array}{c}\mathrm{Ni} \\
(\mathrm{ppm})\end{array}$ \\
\hline $449-13-2,28-30$ & Core $13^{\mathrm{a}}(104.5-111.0)$ & 5.18 & 1.19 & 20.6 & 1.04 & 2.23 & 204 & 48.6 & 365 \\
\hline $449-13-2,128-130$ & & 3.29 & 0.620 & 23.5 & 0.988 & 2.11 & 125 & 39.3 & 347 \\
\hline $449-13-3,19-20$ & & 4.84 & 1.02 & 20.0 & 1.07 & 2.31 & 166 & 51.0 & 366 \\
\hline $449-13-3,65-67$ & & 4.61 & 0.927 & 21.0 & 1.07 & 2.31 & 169 & 52.2 & 335 \\
\hline $449-13-3,114-116$ & & 8.82 & 0.309 & 4.53 & 1.63 & 6.00 & 206 & 92.5 & 395 \\
\hline $449-13-3,124-125$ & & 4.57 & 0.711 & 19.3 & 1.15 & 2.73 & 163 & 54.2 & 366 \\
\hline $449-13-4,19-21$ & & 4.14 & 0.678 & 20.4 & 1.04 & 2.66 & 149 & 51.5 & 381 \\
\hline $449-13-4,81-83$ & & 2.62 & 0.420 & 25.5 & 0.88 & 1.70 & 102 & 35.7 & 320 \\
\hline $449-13-5,16-18$ & & 4.57 & 0.929 & 20.5 & 1.08 & 2.29 & 175 & 49.9 & 347 \\
\hline $449-13-5,20-22$ & & 3.84 & 0.844 & 23.6 & 0.94 & 2.02 & 155 & 44.7 & 357 \\
\hline $449-13-5,62-64$ & & 4.81 & 1.32 & 21.7 & 0.92 & 2.12 & 202 & 46.0 & 340 \\
\hline $449-13-5,75-77$ & & 3.50 & 0.787 & 26.3 & 0.74 & 1.36 & 120 & 46.0 & 528 \\
\hline $449-13-5,90-92$ & & 5.36 & 1.74 & 23.6 & 0.84 & 1.70 & 232 & 52.0 & 393 \\
\hline $449-13-5,94-96$ & & 2.56 & 0.518 & 29.4 & 0.67 & 1.07 & 103 & 44.7 & 377 \\
\hline $449-13-5,135-137$ & & 3.43 & 0.695 & 20.3 & 1.49 & 2.53 & 207 & 48.8 & 533 \\
\hline $449-13-5,142-144$ & & 2.58 & 0.792 & 21.4 & 0.93 & 1.63 & 139 & 33.1 & 342 \\
\hline $449-13-6,5-7$ & & 3.62 & 0.808 & 25.7 & 0.91 & 1.78 & 152 & 39.7 & 379 \\
\hline $449-13-6,21-23$ & & 3.24 & 0.722 & 26.6 & 0.82 & 1.51 & 140 & 51.3 & 330 \\
\hline $449-13-6,38-40$ & & 3.38 & 0.726 & 25.8 & 0.81 & 1.60 & 146 & 44.4 & 353 \\
\hline $449-13-6,48-50$ & & 3.46 & 0.756 & 22.6 & 1.25 & 2.37 & 187 & 37.7 & 389 \\
\hline $449-13-6,56-58$ & & 2.80 & 0.884 & 25.8 & 0.89 & 1.43 & 132 & 48.5 & 440 \\
\hline $449-13-6,95-97$ & & 2.92 & 0.775 & 23.8 & 1.00 & 1.50 & 143 & 48.7 & 363 \\
\hline $449-13-6,119-121$ & & 3.17 & 0.760 & 25.4 & 1.04 & 1.52 & 147 & 33.7 & 426 \\
\hline $449-13-6,132-134$ & & 3.58 & 0.816 & 23.1 & 1.25 & 1.84 & 182 & 43.3 & 421 \\
\hline $450-35-1,4-6$ & Core $35(321.0-330.5)$ & 4.92 & 0.111 & 3.88 & 2.02 & 7.56 & 57.8 & 25.3 & 34.3 \\
\hline $450-35-1,26-28$ & & 5.00 & 0.112 & 3.60 & 1.94 & 7.69 & 65.3 & 25.8 & 32.5 \\
\hline $450-35-1,58-60$ & & 4.26 & 0.115 & 3.55 & 1.85 & 7.22 & 81.0 & 23.1 & 35.9 \\
\hline $450-35-1,85-89$ & & 5.26 & 0.115 & 3.89 & 1.87 & 8.63 & 50.6 & 25.8 & 38.3 \\
\hline $450-35-2,47-50$ & & 4.89 & 0.115 & 2.73 & 2.02 & 8.52 & 43.0 & 29.0 & 39.2 \\
\hline $450-35-2,128-132$ & & 5.06 & 0.112 & 3.11 & 2.05 & 8.64 & 58.2 & 29.4 & 40.0 \\
\hline $450-35-3,0-4$ & & 5.09 & 0.112 & 3.28 & 2.05 & 8.71 & 58.8 & 29.3 & 31.4 \\
\hline $450-35-3,20-25$ & & 5.07 & 0.122 & 3.03 & 1.92 & 8.10 & 64.2 & 27.3 & 28.0 \\
\hline $450-35-3,33-37$ & & 4.39 & 0.123 & 2.59 & 1.78 & 7.62 & 73.6 & 25.2 & 46.0 \\
\hline $450-35-3,42-45$ & & 4.29 & 0.119 & 2.73 & 1.62 & 7.61 & 51.3 & 24.9 & 30.9 \\
\hline $450-35-3,51-54$ & & 4.87 & 0.257 & 2.80 & 1.55 & 7.49 & 76.8 & 25.5 & 50.0 \\
\hline $450-35-3,59-63$ & & 5.72 & 0.736 & 3.56 & 2.37 & 7.91 & 147.1 & 34.0 & 50.5 \\
\hline $450-35-3,64-67$ & & 4.23 & 0.587 & 2.72 & 1.64 & 7.53 & 102.6 & 26.2 & 42.3 \\
\hline $450-35-3,80-83$ & & 2.62 & 0.405 & 1.89 & 1.38 & 6.91 & 110.1 & 23.8 & 41.3 \\
\hline $450-35-3,89-92$ & & 2.94 & 0.322 & 1.98 & 1.33 & 7.14 & 111.4 & 22.2 & 30.3 \\
\hline $450-35-4,0-5$ & & 3.24 & 0.174 & 2.05 & 1.37 & 7.13 & 57.7 & 24.9 & 30.6 \\
\hline $450-36-1,2-5$ & Core $36(330.5-340)$ & 7.65 & 0.917 & 1.18 & 2.44 & 8.73 & 257.2 & 46.7 & 175 \\
\hline $450-36-1,48-51$ & & 6.53 & 0.496 & 1.27 & 2.29 & 9.83 & 212.8 & 42.1 & 134 \\
\hline $450-36-1,112-113$ & & 5.73 & 0.398 & 7.02 & 2.05 & 7.84 & 175.8 & 33.9 & 110 \\
\hline $450-36-1,144-147$ & & 6.20 & 0.349 & 4.82 & 2.11 & 8.28 & 203.6 & 39.0 & 113 \\
\hline $450-36-2,37-41$ & & 6.90 & 0.444 & 1.32 & 2.34 & 9.66 & 245.7 & 47.2 & 148 \\
\hline $450-36-2,86-89$ & & 6.84 & 0.373 & 1.21 & 2.29 & 9.37 & 237.7 & 47.0 & 150 \\
\hline $450-36-2,95-99$ & & 6.82 & 0.445 & 1.23 & 2.28 & 9.33 & 223.0 & 46.8 & 153 \\
\hline $450-36-2,106-109$ & & 7.37 & 0.519 & 1.33 & 2.13 & 9.13 & 277.2 & 48.5 & 188 \\
\hline $450-36-2,115-118$ & & 8.81 & 1.23 & 1.24 & 2.37 & 8.85 & 562.5 & 70.3 & 497 \\
\hline $450-36-2,118-121$ & & 6.78 & 0.848 & 1.13 & 2.42 & 9.06 & 472.9 & 56.9 & 455 \\
\hline $450-36-2,121-124$ & & 5.82 & 0.751 & 1.04 & 2.42 & 9.28 & 414.6 & 62.5 & 451 \\
\hline
\end{tabular}

a Although the cored interval is 6.5 meters, 9.0 meters of sediment were recovered; see Figure 1 caption for an explanation.

indicative of metal enrichment in sediments. All of the samples analyzed from Site 449 fall below the 0.4 value of this ratio.

The metal to aluminum ratios for samples from Cores 35 to 36 of Hole 450 are shown in Figure 2. These sediments, described earlier as not being true basal deposits, show no evidence of metal enrichment when compared to average pelagic clay. In all cases the ratio $\mathrm{Al} /(\mathrm{Al}+\mathrm{Fe}+\mathrm{Mn})$ is greater than 0.4. In fact, the vertical average pelagic-clay ratio lines in Figure 2 suggest these deposits to be unusually low in metals except for iron. The sedimentation rate for this site is listed as $\mathbf{5 0}$ meters per m.y. (Site 450 report, this volume), or 5 to 10 times greater than for Site 449. The mass of basaltic tuff delivered to Site 450 from the West Mariana Ridge apparently accumulated so rapidly that the chemistry of this material dominates the sediment chemistry in this part of the basin and obscures any sign of hydrothermal metal enrichment in the data. It even conceals metal enrichment by normal hydrogenous processes (Bonatti et al., 1972) that account for the relatively high metal content of Pacific sediment.

The metal to aluminum ratios for Site 450 are not without texture, however (Fig. 2). Just above the in- 


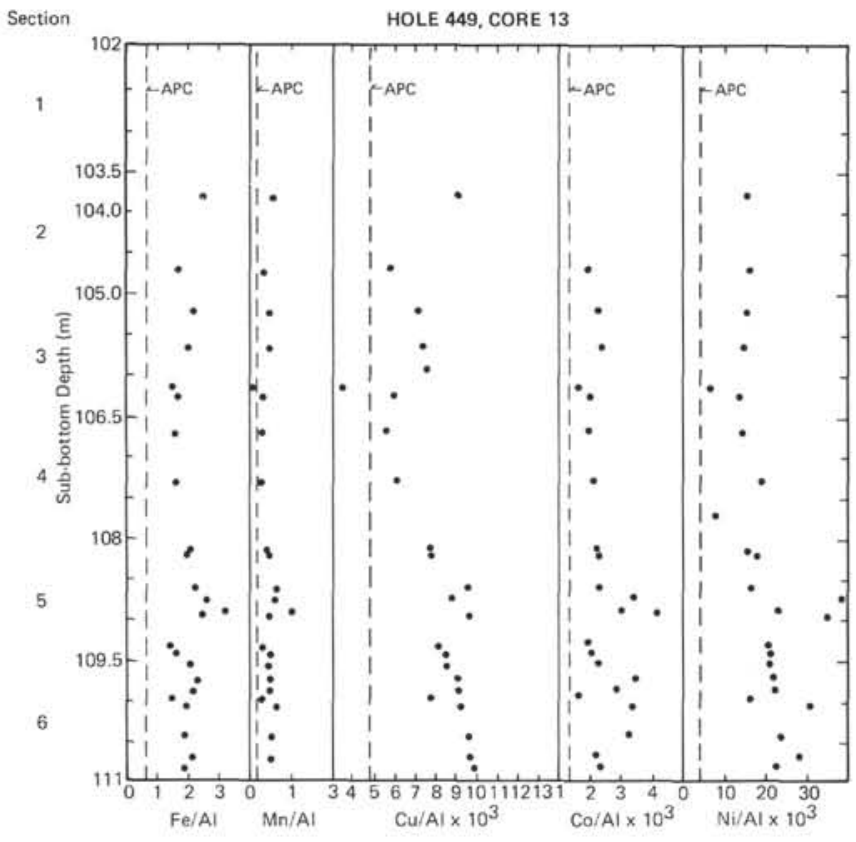

Figure 1. Metal to aluminum ratios for Hole 449. (Vertical dashed lines represent ratios for average Pacific pelagic clay [APC]-see Table 2. Although only a $6.5-\mathrm{m}$ interval was drilled for Core 13 , the entire $9.0 \mathrm{~m}$ of core barrel were filled with soft sediment. Apparently the upper part of Core 13 actually consists of oozes introduced by flow of material from higher in the sequence. A void exists between the last $50 \mathrm{~cm}$ of Section 4 and the first $50 \mathrm{~cm}$ of Section 5 and may separate the admixture of flow material representing the interval immediately above the basalts. Thus the higher metal to aluminum ratios observed at the base of Core 13 probably represent the cored interval.)

Table 2. Average pelagic-clay metal to aluminum ratios.

\begin{tabular}{lccccc}
\hline & $\mathrm{Fe} / \mathrm{Al}$ & $\mathrm{Mn} / \mathrm{Al}$ & $\mathrm{Cu} / \mathrm{Al} \times 10^{3}$ & $\mathrm{Co} / \mathrm{Al} \times 10^{3}$ & $\mathrm{Ni} / \mathrm{Al} \times 10^{3}$ \\
\hline $\begin{array}{l}\text { Average Pacific } \\
\begin{array}{l}\text { Pelagic Clay (APC) } \\
\text { Average Altantic }\end{array}\end{array}$ & 0.61 & 0.11 & 4.8 & 1.3 & 3.6 \\
$\begin{array}{l}\text { Pelagic Clay } \\
\text { ( }\end{array}$ & 0.56 & 0.04 & 1.3 & 0.4 & 0.9 \\
\hline
\end{tabular}

a Turekian and Imbrie, 1966; Landergren, 1964, from Bischoff and Rosenbaum, 1977; Dymond et al., 1973.

b Turekian and Imbrie, 1966; Cronan, 1972; Boström and Valdes, 1969; Horowitz and Cronon, 1976; Van der Weidjen et al.. 1970; El Wakeel and Riley, 1961.

trusive basalt, all of the metals increase abruptly in what has been referred to as the metamorphic aureole (Kroenke and Scott, 1978). There is also a strong Mn spike in the middle of Core 35 that is associated with $\mathrm{Fe}, \mathrm{Cu}$, and Co increases. However, neither of these features can be interpreted unequivocally as the result of hydrothermal activity at a spreading center.

We conclude that basal sediments at Site 449 in the western Parece Vela Basin have been enriched in metals, probably by a hydrothermal process related to back-arc spreading. Metal-enriched basal sediments have been found by Bonatti et al. (1979) in the West Philippine Basin, which is west of the Parece Vela Basin and separated from it by the Palau-Kyushu Ridge. Bonatti et al. (1979) have also concluded that the metal enrichment is the result of hydrothermal processes related to spreading.

The lack of mirror-image metal enrichments in basal sediments from Site 450 may be attributed to two fac-

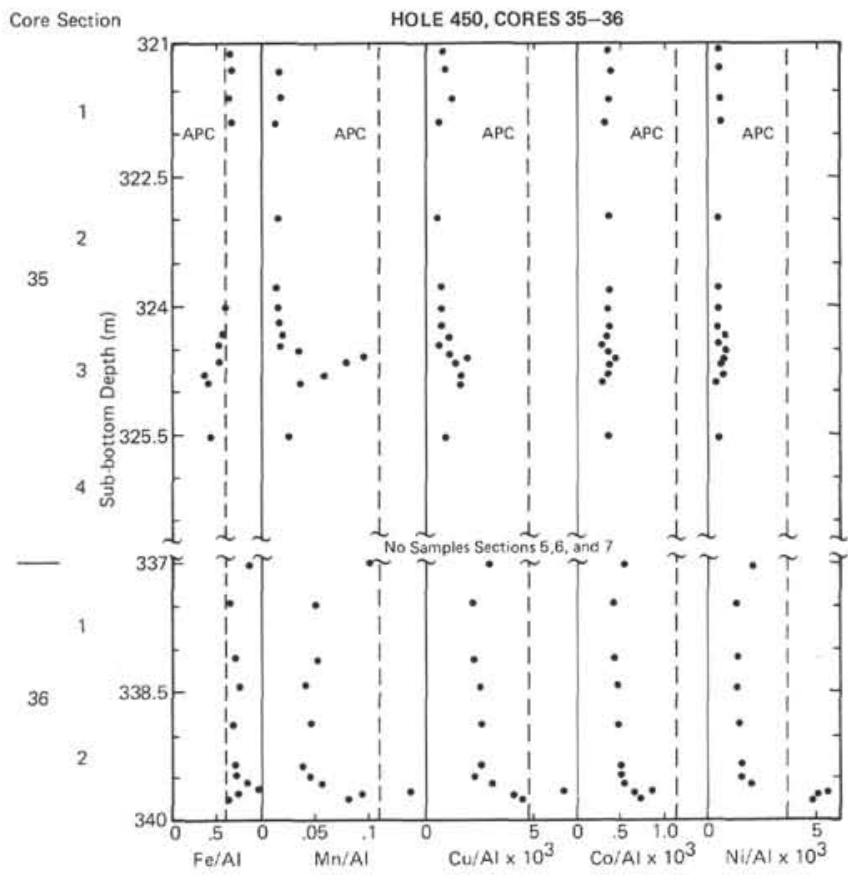

Figure 2. Metal to aluminum ratios for Hole 450. (Vertical dashed lines represent ratios for average Pacific Pelagic Clay [Table 2].)

tors: (1) these sediments probably lie well above the true basement and are in contact with an intrusive basalt, and (2) the accumulation rate of tuffaceous sediment from the West Mariana Ridge may have been so great as to obliterate any evidence of hydrothermal metal enrichment.

\section{ACKNOWLEDGMENT}

We thank Drs. Andrew Hajash and Robert Scott for reviewing this paper.

\section{REFERENCES}

Bischoff, J. L., and Rosenbaum, R. J., 1977. Recent metalliferous sediment in the North Pacific manganese nodule area. Earth Planet. Sci. Lett., 33:379-388.

Bonatti, E., Kolla, V., Moore, W. S., et al., 1979. Metallogenesis in marginal basins: Fe-rich basal deposits from the Philippine Sea. Mar. Geol., 32:21-37.

Bonatti, E., Kraemer, T., and Rydell, H., 1972. Classification and genesis of submarine iron-manganese deposits. In Horn, D. R., (Ed.), Ferromanagese Deposits of the Ocean Floor: Washington (IDOE), pp. 149-165.

Boström, K., 1970. Geochemical evidence for ocean-floor spreading in the South Atlantic Ocean. Nature, 227:1041.

, 1975. The origin and fate of ferromanganoan ridge sediments. Stockholm Contrib. Geol., 27:149-241.

Boström, K., and Peterson, M. N. A., 1969. Origin of aluminumpoor ferromanganoan sediments in areas of high heat flow on the East Pacific Rise. Mar. Geol., 7:427-447.

Boström, K., and Valdes, S., 1969. Arsenic in the ocean floor. Lithos, $2: 351-360$

Cronan, D. S., 1972. The Mid-Atlantic Ridge near $45^{\circ} \mathrm{N}: X V I I$. Al, $\mathrm{As}, \mathrm{Hg}$, and $\mathrm{Mn}$ in ferrugenous sediments from the median valley. Can. J. Earth Sci., 9:319-323.

Dymond, J., Corliss, J. B., Heath, G. R., et al., 1973. Origin of metalliferous sediments from the Pacific Ocean. Bull. Geol. Soc. $A m$., 84:3355-3372.

El Wakeel, S. K., and Riley, J. P., 1961. Chemical and mineralogical studies of deep-sea sediments. Geochim. Cosmochim. Acta, 25: 110-146. 
Flanagan, F. J., 1973. 1972 values for international geochemical reference samples. Geochim. Cosmochim. Acta, 37:1189-1200.

Horowitz, A., and Cronan, D. S., 1976. The geochemistry of basal sediments from the North Atlantic Ocean. Mar. Geol., 20:205228.

Karig, D. E., 1975. Basin genesis in the Philippine Sea. In Karig, D. E., Ingle, J. C., Jr., et al., Init. Repts. DSDP, 31: Washington (U.S. Govt. Printing Office), 857-879.

Kroenke, L., and Scott, R., 1978. Old questions answered-and new ones asked. Geotimes, 23:20-23.
Manheim, F. T., Hathaway, J. L., Flanagan, F. J., et al., 1976. Marine mud, MAG-1, from the Gulf of Maine. In Flanagan, F. J. (Ed.), Descriptions and Analyses of Eight New USGS Rock Standards: Geological Survey Professional Paper 840: Washington U.S. Govt. Printing Office).

Turekian, K. K., and Imbrie, J., 1966. The distribution of trace elements in deep-sea sediments of the Atlantic Ocean. Earth Planet. Sci. Lett., 1:161-168.

Van der Weijden, C. H., Schuiling, R. D., and Das, H. A., 1970. Some geochemical characteristics of sediments from the North Atlantic Ocean. Mar. Geol., 9:81-99. 